\title{
POLA PENERAPAN METODE TARGHIB WA TARHIB PADA PEMBELAJARAN TAHSIN TAHFIDZ DI SMPIT BINA INSANI KOTA METRO
}

\author{
Oleh. \\ Iswati \\ Universitas Muhammadiyah Metro \\ iswatiummetro@yahoo.com
}

\begin{abstract}
The application of targhib and tarhib methods in tahsin and tahfidz lessons does not necessarily solve problems that arise in the learning process, because the application of a method has consequences in the form of challenges and obstacles that require a way out.This study aims to explore the pattern of the application of the targhib and tarhib method in tahsin and tahfidz learning at the Bina Insani Middle School in Metro City. The process of collecting data using the method of observation, interviews, and documentation to achieve valid and representative data. The results showed that the implementation of the targhib and tarhib methods in tahsin and tahfidz lessons had a side of effectiveness and problematics but were still in the level of being able to be handled well by schools and teachers. Targhib and Tarhib have given to students at Bina Insani Middle School at Metro City, have been in accordance with the education corridor and have been agreed upon between the School, Teachers, Student, and Student Guardians.
\end{abstract}

\section{Key word: Method, Targhib,Tarhib, Tahsin, Tahfidz.}

\begin{abstract}
Abstrak
Penerapan metode targhib dan tarhib dalam pelajaran tahsin dan tahfidz tidak serta merta menyelesaikan masalah yang muncul dalam proses pembelajaran, karena penerapan metode memiliki konsekuensi berupa tantangan dan hambatan yang membutuhkan jalan keluar. Penelitian ini bertujuan untuk mengeksplorasi pola penerapan metode targhib dan tarhib dalam pembelajaran tahsin dan tahfidz di Sekolah Menengah Bina Insani di Kota Metro. Proses pengumpulan data menggunakan metode observasi, wawancara, dan dokumentasi untuk mencapai data yang valid dan representatif. Hasil penelitian menunjukkan bahwa penerapan metode targhib dan tarhib dalam pelajaran tahsin dan tahfidz memiliki sisi efektivitas dan masalah tetapi masih dalam tingkat yang dapat ditangani dengan baik oleh sekolah dan guru. Targhib dan Tarhib telah diberikan kepada siswa di Sekolah Menengah Bina Insani di Kota Metro, telah sesuai dengan koridor pendidikan dan telah disepakati antara Sekolah, Guru, Siswa, dan Wali Siswa.
\end{abstract}

Kata kunci: Metode, Targhib, Tarhib, Tahsin, Tahfidz. 


\section{A. PENDAhuluan}

Keberhasilan seorang pendidik dalam menyampaikan materi di kelas tidak hanya tergantung dari bagaimana kompetensi guru dalam pengusaan materi pembelajaran, akan tetapi ada unsur lain yang juga cukup menentukan berhasil tidaknya suatu proses pembelajaran di kelas yaitu metode. Tidak berhasilnya akan tertanamnya nilai-nilai rohaniah terhadap peserta didik dewasa ini sangat terkait dengan dua faktor penting di samping banyak faktor lainnya, kedua faktor tersebut adalah mentalitas pendidik dan metode pendidikan. ${ }^{1}$ Dengan demikian guru harus piawai dalam menerapkan variasi penggunaan metode yang relevan dengan materi pembelajaran, sehingga cara yang dilakukan dengan teratur dan terpogram untuk mencapai tujuan yang diinginkan ${ }^{2}$. Metode ialah semua cara yang digunakan dalam upaya mendidik. ${ }^{3}$ Dalam literatur pendidikan Islam diketahui banyak metode yang dapat diterapkan dalam proses pembelajaran, satu di antaranya adalah metode Targhib wa Tarhib yang berarti pemberlakuan pemberian hadiah dan hukuman dalam pembelajaran. Targhib

1 Erwin Yudi Prahara, Metode Targhib Wa Tarhib dalam Pendidikan Islam, Jurnal Cendekia Vol.13 No.1, Januari-Juni 2015, h.2.

2 M.Ihsan Dacholfany, Inisiasi Strategi Manajemen Lembaga Pendidikan Islam Dalam Meningkatkan Mutu Sumber Daya Manusia Islam di Indonesia Dalam menghadapi Era Globalisasi, Jurnal At-Tajdid, Volume 1, No.1 Januari-Juni, 2017, h.4.

${ }^{3}$ Ahmad Tafsir, Ilmu Pendidikan dalam Perspektif Islam, Bandung: Remaja Rosda Karya, 2004, h.131. dan Tarhib merupakan sebuah metode yang sudah begitu dikenal dalam Pendidikan Islam. Metode ini efektif guna membantu guru dan siswa saling berinterkasi dalam menunjang keberhasilan.

Di SMP IT Bina Insani Kota Metro, khususnya pada pembelajaran tahsin tahfidz, baik sekolah maupun guru telah membuat perencanaan dan rambu-rambu pembelajaran yang harus dipatuhi siswasupaya tujuan belajar dapat tercapai dan menjaga suasana belajar tetap kondusif. "Ketika ramburambu pelajaran di langgar seperti siswa tidak setor hafalan karena alasan yang disengaja atau siswa membuat pelanggaran selama pelajaran maka guru memberikan tarhib, dan ketika seorang siswa mendapat prestasi maka guru wajib memberikan targhib sebagai sarana untuk memotivasi dan meningkatkan semangat belajar siswa". ${ }^{4}$

Metode ini merupakan salah satu metode yang digunakan oleh guru dengan tujuan untuk menjaga dan mempertahankan ritme kegiatan menghafal dan menjaga supaya hafalan-hafalan yang sudah diingat tidak hilang karena tidak adanya konsistensi serta upaya penekanan untuk memelihara hafalan yang sudah terprogram dan terencana dengan baik, karena jika kelalaian tersebut di atas dibiarkan secara terus menerus tanpa ada upaya penyelesaian dan pencegahan tentu akan berdampak

${ }^{4}$ Wawancara Bagus Prayoga, Guru SMP IT Bina Insani Kota Metro, pada tanggal 6 Desembember 2108. 
kepada menurunnya intensitas belajar dan hasil belajar para siswa walaupun faktanya penerapan metode ini tidak serta merta menyelesaikan masalah yang muncul, karena penerapan suatu metode memiliki konsekuensi berupa tantangan dan hambatan yang memerlukan jalan keluar, akan tetapi upaya prefentif sudah dilakukan oleh pihak sekolah secara efektif dan efesien sesuai dengan tujuan ${ }^{5}$.

\section{B. METODOLOGI PENELITIAN}

Penelitian yang penulis gunakan dalam penelitian ini adalah penelitian kualitatif. Penelitian kualitatif adalah penelitian yang tidak memfokuskan pada keleluasaan tetapi lebih menekankan pada aspek "kedalaman" hasil penelitian. Analisis fakta lebih menekankan pada tehnik reflektive thinking, rasionalitas, relevansi, signifikansi dan kepekaan peneliti terhadap lingkungan penelitian. Penelitian Kualitatif lebih bersifat holistic dan teoritik. ${ }^{6}$ Dalam penelitian ini penulis terlibat langsung sebagai observer terhadap fenomena atau gejala-gejala yang terdapat di lapangan untuk mengetahui situasi umum dari obyek yang diteliti dan untuk memperoleh data tentang kegiatan responden.

5 M.Ihsan Dacholfany, Inisiasi Strategi Manajemen Lembaga Pendidikan Islam Dalam Meningkatkan Mutu Sumber Daya Manusia Islam di Indonesia Dalam menghadapi Era Globalisasi, Jurnal At-Tajdid, Volume 1, No.1 Januari-juni, 2017, h.13.

${ }^{6}$ Basrowi dan Suwandi, Memahami Penelitian Kualitatif, Jakarta: Rineka Cipta, 2008, h.20.

\section{PEMBAHASAN}

\section{Pengertian Penerapan}

Menurut kamus besar Bahasa Indonesia, "pengertian penerapan adalah pengenaan, perihal mempraktikkan"7.Penerapan adalah melaksanakan kegiatan yang telah direncanakan dan ditetapkan tujuannya secara berkesinambungan, terprogram, dievaluasi dan mendapat tindak lanjut dari pembuat program. Dalam hal ini program yang sedang diterapkan adalah kegiatan tahsin dan tahfidz di SMP IT Bina Insani Kota Metro.

\section{Targhib wa tarhib}

Secara psikiologis dalam diri manusia ada potensi kecendrungan untuk berbuat kebaikan dan keburukan (al fujur wa taqwa), oleh karena itu pendidikan Islam berupaya mengembangkan manusia dalam berbagai cara guna melakukan kebaikan dengan berbekal keimanan, sebaiknya pendidikan Islam berupaya semaksimal mungkin menjauhkan manusia dari perbuatan buruk dengan berbagai aspeknya. Kata Targhib diambil dari kata kerja raghaba yang berarti menyenangi, menyukai dan mencintai, kemudian kata itu diubah menjadi menjadi kata benda targhib yang mengandung makna suatu harapan utuk memperoleh kesenangan, kecintaan, kebahagiaan.

Targhib adalah janji terhadap kesenangan, kenikmatan akhirat yang disertai bujukan, sedangkan tarhib adalah "ancaman karena dosa yang

\footnotetext{
${ }^{7}$ Depdikbud, Kamus Besar Bahasa Indonesia, Jakarta: Balai Pustaka, 2002, h. 935 .
} 
dilakukan". ${ }^{8}$ Semua itu dimunculkan dalam bentuk janji-janji berupa keindahan dan kebahagiaan yang dapat merangsang seseorang sehingga timbul harapan dan semangat untuk memperolehnya. Secara psikologis, cara itu akan menimbulkan daya tarik yang kuat untuk menggapainya, sementara Tarhib muncul sebagai reaksi oleh guru dikarenakan adanya ketidaksesuaian antara realita dan harapan guru dan sekolah kepada siswa dikarenakan perilaku menyimpang siswa.

Perilaku menyimpang dapat didefinisikan sebagai suatu perilaku yang diekspresikan oleh seorang atau beberapa orang anggota masyarakat yang secara disadari atau tidak disadari, tidak menyesuaikan diri dengan normanorma yang berlaku yang telah diterima oleh sebagian besar anggota masyarakat. ${ }^{9}$ Penyimpangan atau kondisi tersebut bisa disebabkan karena anak dalam keadaan tidak sadar atau khilaf, manusia atau dalam hal ini adalah siswa yang melakukan pelanggaran atau sedang tidak berada dalam ketaatan maka dalam pandangan Islam disebut dengan keadaan futur.

Targhib wa tarhib merupakan salah satu teknik pendidikan yang bertumpu pada fitrah manusia dan keinginannya pada imbalan, kenikmatan, dan kesenangan, teknik itu pun bertumpu pada rasa takut manusia terhadap hukuman, kesulitan, dan

8 Ramayulis, Metodologi Pendidikan Agama Islam, Jakarta: Kalam Mulia,2005, h.293.

9 Tim Sosiologi, Panduan Belajar Sosiologi, Jakarta: Yudhistira, 1994, h.54. akibat buruk. ${ }^{10}$ Berdasarkan konsep diatas, penulis berpendapat bahwa pengertian targhib adalah pemberian penghargaan atau reward kepada siswa yang mendapatkan prestasi belajar dan tarhib adalah memberikan sanksi atau hukuman bagi yang tidak taat terhadap peraturan yang berlaku.

Targhib wa tarhib bukanlah metode utama dalam pengajaran tahsin dan tahfidz, melainkan metode tambahan yang digunakan guru dalam rangka menunjang pencapaian hasil belajar yang maksimal. Metode mengajar adalah "kesatuan langkah kerja yang dikembangkan oleh guru berdasarkan pertimbangan rasional tertentu, masing-masing jenisnya bercorak khas dan kesemuanya berguna untuk mencapai tujuan pengajaran tertentu". ${ }^{11}$

Hukuman dalam pendidikan memiliki pengertian yang luas, mulai dari hukuman ringan berupa bahasa tubuh yang tidak respect, kerlingan mata, bermuka masam, teguran hingga sampai pada hukuman berat berupa sanksi. Pemberian tarhib sebagai peringatan disesuaikan dengan kesalahan dan pelanggaran yang dilakukan oleh siswa tersebut. Sebaiknya guru yang hendak menjadikan sanksi sebagai tehnik pendidikan atau untuk mengontrol siswa di dalam kelas dapat memperhatikan hal-hal sebagai berikut: Pertama, sanksi itu sendiri bukan

10 Ahmad Ali Budaiwi, Imbalan dan Hukuman Pengaruhnya Bagi Pendidikan Anak, Jakarta: Gema Insani Press, 2002, h.8.

${ }^{11}$ Suryosubroto, B. Proses Belajar Mengajar Di Sekolah, Jakarta: PT Rineka Cipta, 2009, h. 27-28. 
merupakan tujuan, tetapi sanksi merupakan sarana untuk memperbaiki perilaku siswa. Kedua, penting sekali anak yang dikenai sanksi memahami tujuan dibalik sanksi itu, yaitu keinginan guru yang kuat untuk memperbaiki muridnya dan membimbingnya pada jalan pembelajaran. Perbaikan itu dilakukan melalui pemberian sanksi dan melalui kondisi psikologis guru, namun hendaknya guru waspada agar murid tidak merasa diintimidasi atau ingin balas dendam. Ketiga, sanksi disesuaikan dengan besarnya kesalahan yang dilakukan murid, tidak boleh kurang atau lebih. Hal itu karena apabila merasakan sanksi yang melebihi kesalahannya, timbul dalam hatinya perasaan diintimidasi dan dikhianati.Keempat, guru hendaknya memahami bahwa siswa mereka itu bervariasi dan berbeda. Ada murid yang tidak menjadi baik kecuali dengan pukulan, berbeda dengan murid yang cukup diperbaiki dengan pandangan marah; bahwa sanksi yang cocok untuk kesalahan tertentu belum tentu cocok untuk kesalahan lainnya.Kelima, guru jangan cepatcepat memberikan sanksi kepada siswanya sebelum mereka beroleh keyakinan bahwa muridnya memang berhak mendapatkan sanksi. Hal itu karena apabila sanksi tidak sesuai dengan kesalahannya, murid akan merasa diintimidasi dan dizhalimi, demikian pula seluruh murid dikelas. Keenam, sanksi dihentikan dengan terhentinya sikap yang menimbulkan sanksi itu. Tidak boleh mempermalukan murid karena perbuatannya atau menceritakan kesalahan karena dia diberi sanksi. Guru harus sadar bahwa sebagian murid suka mempermalukan temantemannya yang menerima sanksi. Ketujuh, sanksi harus diberikan untuk memperbaiki perilaku individu demi kebaikan kelompok. Ketika guru memberikan sanksi karena suatu kesalahan maka guru itu merupakan bagian dari kelompok besar yang memiliki rasa tanggung jawab sosial, oleh karenanya, sanksi itu tidak boleh sesuai dengan selera pribadi atau demi keuntungan yang diharapkan. Kedelapan, jika sanksi atas kesalahan itu dilaksanakan didepan umum supaya kesalahannya itu tidak menyebar ke anggota kelompok yang lain, imbalanpun harus diberikan di depan banyak orang dan di depan kelompok yang sama, sehingga memungkinkan terjadinya penguatan perilaku positif. Kesembilan, adalah penting bagi guru dan murid untuk memahami makna pendidikan yang ada dibalik sanksi, yaitu dengan menjelaskan sikap guru dan unsur-unsurnya secara lengkap setelah dia memberikan sanksi, agar guru tidak kehilangan ikatan kasih sayang dengan murid-murid. Kesepuluh, guru sebaiknya menginformasikan kepada para wali murid tentang sanksi dan alasan menggunakannya, sanksi diberikan untuk menjamin kontinuitas perbaikan perilaku yang keliru dan menghindari pengulangan dimasa yang akan datang. ${ }^{12}$ 
Hukuman tidak boleh diberikan kecuali dalam keadaan terpaksa dan tidak ada pilihan lain dan dengan terlebih dahulu memberikan peringatan dan himbauan sebagaimana firman Allah SWT, yang artinya:

"Serulah manusia kepada jalan Tuhanmu dengan hikmah dan pelajaran yang baik dan bantahlah mereka dengan cara yang baik. Sesungguhnya Tuhanmu Dialah yang paling mengetahui tentang siapa yang tersesat dari jalan-Nya dan Dialah yang lebih mengetahui orang-orang yang mendapat petunjuk" (Q.S. AlNahl: 125). ${ }^{13}$

Tarhib (Hukuman) dalam pendidikan mempunyai porsi penting, pendidikan yang terlalu bebas dan ringan akan membentuk anak didik yang tidak disiplin dan tidak mempunyai keteguhan hati, namun sanksi yang baik adalah yang tidak serta merta dilakukan, apalagi ada rasa dendam. Sanksi dapat dilakukan dengan bertahap, misalnya dimualai dengan teguran, kemudian diasingkan dan seterusnya dengan catatan tidak menyakiti dan tetap bersipat mendidik. Konsep pemberian tarhib dalam Islam lebih menekankan kepada pemberian peringatanmelalui cara-cara yang halus, bijak dan cerdas tanpa mengedepankan unsur kekerasan. Rasulullah SAW bersabda ;

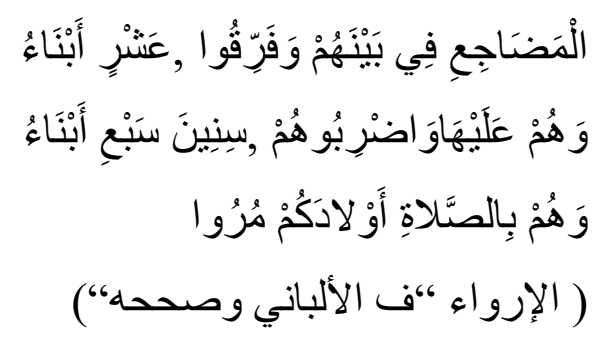

"Perintahkanlah anak-anak kalian untuk mengerjakan shalat ketika berusia tujuh tahun, dan pukulah mereka jika tidak mengerjakan shalat pada usia sepuluh tahun, dan pada usia tersebut juga pisahkanlah tempat tidur mereka (laki-perempuan).“14

Menghukum anak bukan perkara yang mudah karena masalah tidak hanya selesai saat seorang guru bisa menahan amarahnya, akan tetapi masalah yang paling penting adalah dampak dari hukuman tersebut, apakah anak mengalami perubahan positif atau malah sebaliknya anak mengalami perubahan yang negatif. Dalam beberapa fenomena yang terjadi adalah anak mengalami mogok belajar, dan cenderung bersikap pasif terhadap materi yang diberikan guru. ${ }^{15}$

Uraian di atas dapat menjadi rambu-rambu bagi guru untuk lebih berhati-hati dalam memberikan tarhib kepada siswa, tarhib hanya merupakan satu cara sederhana untuk mencegah terjadinya pelanggaran terhadap peraturan, tidak mengulangi

\footnotetext{
${ }^{14} \mathrm{https}: / /$ www.alsofwah.or.id/cetakhad its.php?id=247 diunduh tanggal 27 September 2018.

15 Luthfiana. Problematika Implementasi Educative Punishment Untuk Anak Usia Dini Dan Upaya Solusinya di TK Zainul Hasan Genggong Pajarakan Probolinggo. Skripsi IAIN Sunan Ampel. Surabaya : Program Studi Strata Satu Tarbiyah. 2008, h.5.
} 
kesalahannya dan untuk mencegah agar anak-anak lain tidak menirunya.

\section{PembelajaranTahsin dan Tahfidz}

a. Pengertian Tahsin

Tahsin berasal dari bahasa Arab yaitu hassana-ahsana yang artinya membaguskan. Kata ini sering digunakan sebagai sinonim dari kata tajwid yang berasal dari jawwadayujawwiduyang dalam bahasa Arab memiliki arti "memperbaiki, meningkatkan, atau memperkaya. ${ }^{16}$ Tahsin dalam Islam mengandung makna bahwa setiap muslim di tuntut agar dapat membaca Al-Qur'an dengan benar dan tepat sesuai dengan contohnya demi terjaganya orisinalitas praktik tilawah sesuai dengan sunnah Rasulullah SAW.

Tahsin atau tajwid adalah "mengeluarkan setiap huruf-huruf alQuran dari tempat keluarnya dengan memberikan hak dan mustahaknya, atau dengan kata lain menyempurnakan semua hal yang berkaitan dengan kesempurnaan pengucapan huruf-huruf al-Quran dari aspek sifat-sifatnya yang senantiasa melekat padanya dan menyempurnakan pengucapan hukum hubungan antara satu huruf dengan yang lainnya seperti idzhar, idgham, ikhfa dan sebagainya. ${ }^{17}$

$\begin{array}{ccr}\text { b. Pengertian } & \text { Tahfidz } & \\ \text { Istilah } & \text { Tahfidz } & \text { berarti } \\ \text { memelihara, } & \text { menjaga } & \text { atatu }\end{array}$

16 Mahmud Yunus, Kamus ArabIndonesia, Jakarta: PT. Mahmud Yunus Wadzurriyyah, 1989, h.103.

${ }^{17}$ https://id.wikipedia.org/wiki/Tahsin diunduh tanggal 24 Oktober 2018 menghafal. ${ }^{18}$ Tahfidz merupakan proses menghafal dan menjaga hafalan AlQur'an agar siswa memiliki kompetensi hafalan yang baik. Pelajaran ini difokuskan kepada melatih daya ingat siswa, "ingatan adalah penarikan kembali informasi yang pernah diperoleh sebelumnya". ${ }^{19}$ Progam tahsin dan tahfidz al-Qur'an mempunyai peran penting dalam upaya mengembangkan pendidikan agama Islam.

Pelajaran tahsin dan tahfidz merupakan program tindak lanjut dari penyelenggaraan pembelajaran baca, tulis dan tahfidz Al-Qur'an di lingkungan sekolah yang sejalan dengan amanat PP. Nomor 55 tahun 2007 tentang Pendidikan Agama dan keagamaan pasal 24 dan 25 yang menjelaskan bahwa pendidikan AlQur'an bertujuan untuk meningkatkan kemampuan peserta didik dalam hal membaca, menulis, memahami dan mengamalkan kandungan Al-Qur'an dalam kehidupan sehari-hari. ${ }^{20}$

Konsistensi atau istiqomah adalah hal terberat dalam proses pelajaran tahsin dan tahfidz, sebagaimana yang disabdakan oleh Rasulullah SAW, "Sesungguhnya perumpamaan penghafal Al-Qur'an itu seperti unta yang terikat. Jika ia bisa mempertahankan unta itu, maka ia bisa menahannya, dan jika dilepaskan, maka

18 Mahmud Yunus, op.cit., h.77

${ }^{19}$ Slameto, Belajar Dan Faktor-

Faktor Yang Mempengaruhinya, Jakarta: Rineka Cipta, 2010, h.111

${ }^{20}$ Abd. Rosyid, Pandai, Baca, Tulis \& Tahfidz Al-Qur'an untuk SMP Kelas IX, Jakarta: Erlangga, 2014, h.2 
ia pun pergi”. (HR. Bukhari dan Muslim)

Pelaksanaan pelajaran tahsin dan tahfidz di SMP IT Bina Insani terfokus pada pencapaian atau hasil hafalan Al-Qur'an para siswa selama menempuh masa pendidikan (tiga tahun) yang di terapkan melalui mata pelajaran yang diberikan secara terjadwal dan intensif.

\section{Pandangan Ilmuwan Muslim Terkait Metode Targhib wa Tarhib}

Tidak ada ahli pendidikan yang menghendaki digunakannya hukuman dalam pendidikan kecuali bila terpaksa. Hukuman itu tidak boleh berupa siksaan, baik badan maupun jiwa. Bila keadaan amat memerlukan hukuman, maka hukuman itu harus digunakan dengan sangat hati-hati. Tabiat baik perlu diarahkan dengan memberikan imbalan dan penguatan, sedangkan tabiat buruk perlu diantisipasi dan mendapat penanganan. Cara pengarahan ini dikenal dalam AlQur'an dengan metode targhib wa tarhib. Dalam penjelasan mengenai tarhib wa tarhib atau hukuman dan penghargaan ini, penulis paparkan beberapa pendapat ulama dan ahli pendidikan, yaitu :

\section{a. Pandangan Al-Qabasi tentang \\ Imbalan dan Hukuman}

Ditetapkanlah hukuman sesuai dengan dosa (proporsional). Anak diberlakukan dengan keras dalam kerangka kasih sayang, semangat kemanusiaan dan penyelamatan atas kemuliaan manusia serta dilakukan dalam suasana
sayang.Pandangan

Al-Qabasi terungkap dari pengalamannya yang luas dalam bidang pendidikan dan pengajaran, beliau berpesan agar guru mengasihi muridnya, berlaku lembut dan memberikan nasehat yang tulus kepada mereka, seyogyanya guru berperan sebagai pengganti orang tua. pandangannya adalah "di antara bentuk perhatian yang baik kepada murid adalah guru sayang muridnya". ${ }^{21}$

\section{b. Pandangan Al-Ghazali}

Imam Al-Ghazali berpendapat bahwa "hukuman yang diberikan kepada anak saat terjadi pelanggaran haruslah hukuman yang mendidik". ${ }^{22}$ Artinya hukuman itu harus memiliki karakteristik tersendiri yang didasarkan atas tujuan kemaslahatan, bukan untuk menghancurkan perasaan pelajar, menyepelekan harga dirinya dan menghinakan dirinya. Diharapkan para guru memberikan nasihat kepada para siswa dengan kelembutan, jika anak memperlihatkan suatu kemajuan, semestinya guru memuji hasil upaya muridnya, berterima kasih kepadanya serta mendukungnya terutama di hadapan teman-temannya guna menjadikannya sebagai model dan teladan yang harus diikuti.

c. Pandangan Ibnu Sina

Ibnu Sina berpendapat bahwa "hukuman kepada anak-anak patut diberikan apabila mereka melakukan

${ }^{21}$ Ahmad Ali Budaiwi, Imbalan dan hukuman Pengaruhnya bagi Pendidikan Anak), Jakarta: Gema Insani, 2002, h. 22. ${ }^{22}$ ibid, h.25. 
kesalahan". ${ }^{23}$ Hal ini bertujuan untuk membentuk akhlak pribadi diri, mendidik disiplin, serta memberi kesadaran dalam diri mereka. Setiap hukuman yang diberikan juga dapat mendidik anak-anak supaya mereka nantinya dapat meneliti terlebih dahulu apa akibat dari kesalahan yang mereka lakukan, sehingga secara tidak langsung mereka akan lebih berhatihati dari melakukan kesalahan.

\section{Tinjauan Historis SMPIT Bina Insani}

SMP IT Bina Insani Kota Metro mulai beroperasi pada tahun 2011, secara geografis letak SMP IT Bina Insani sangat strategis karena berada di tengah desa yang mudah dijangkau oleh masyarakat dan berada pada perlintasan utama jalan Jl. Dr. Soetomo 28 Purwoasri Kecamatan Metro Utara Kota Metro. Lampung.

SMP IT Bina Insani Kota Metro didirikan bermula dari pandangan bahwa Kota Metro masih membutuhkan sekolah swasta terutama sekolah-sekolah Islami yang berkualitas, hal ini dikarenakan sekolah-sekolah swasta yang ada umumnya didominasi atau dimiliki oleh yayasan non muslim ataupun sekolah negeri milik pemerintah yang ada belum sepenuhnya memenuhi ekspektasi atau harapan dari orang tua, terutama sekolah menengah pertama yang memiliki kepedulian terhadap akhlak, kepribadian dan keunggulan dalam bidang baca dan tulis Al-Qur'an.

${ }^{23}$ Rahman Assegaf, Aliran Pemikiran Pendidikan Islam Hadharah Keilmuan Tokoh Klasik Sampai Modern, Jakarta: PT. Raja Grafindo, 2012, h. 97.
Tujuan dari didirikannya SMP IT Bina Insani Kota Metro ini adalah untuk membentuk anak Indonesia yang berkualitas, khususnya anak-anak di Kota Metro agar tumbuh dan berkembang menjadi generasi sholeh dan sholehah serta membentuk karakter siswa yang karim-karimah sebagaimana tujuan pendidikan yang terdapat dalam undang-undang nomor 20 tahun 2003 tentang sistem pendidikan nasional.

Sekolah Islam Terpadu adalah sekolah yang mengimplementasikan konsep pendidikan Islam yang berlandaskan Al-Qur'an dan AsSunnah. Konsep operasional Sekolah Islam Terpadu merupakan akumulasi dari proses pembudayaan, pewarisan dan pengembangan ajaran agama Islam, budaya dan peradaban Islam dari generasi ke generasi. Istilah "TERPADU" dalam Sekolah Islam Terpadu dimaksudkan sebagai penguat dari nilai-nilai Islam itu sendiri. Maksudnya adalah nilai-nilai dari agama Islam yang utuh, menyeluruh dan Integral bukan parsial.Dengan dilandasi oleh semangat yang terdapat dalam dalam Al-Qur'an bahwa umat Islam adalah Khoiru Ummah (umat terbaik) yakni umat yang seharusnya punya keunggulan-keunggulan dibanding dengan umat lain, maka motto SMP IT Bina Insani Kota Metro adalah "Sekolahnya Para Juara Pemburu Sukses Dunia-Akherat".

Visi SMPIT Bina Insani Kota Metro adalah "Sholeh, pemimpin profesional, entrepreneurship untuk meraih sukses dunia-akhirat". Maksud dari visi ini adalah ingin menjadikan 
peserta didik menjadi generasi yang beriman dan bertakwa terhadap Allah SWT, mempunyai kecerdasan akal pikiran dan penguasaan teknologi dan informasi, mempunyai akhlaq mulia dalam bergaul dan berkomunikasi dengan lingkungannya dan handal dalam menyikapi perkembangan teknologi informasi dan komunikasi serta mampu mengubah tantangan menjadi peluang. Kepala sekolah berharap visi SMP IT Bina Insani Kota Metro dapat tercapai pada tahun 2019.

Misi adalah langkah-langkah yang dilakukan sekolah dalam rangka tercapainya visi sekolah. Berikut ini misi SMP IT Bina Insani Kota Metro.

1) Membangun pribadi siswa dengan integritas spiritual, emosional, intelektual dan fisik.

2) Mendidik siswa menjadi pemimpin yang mampu mensinergikan antara keluarga, masyarakat, tim dan generasi penerus.

3) Menjadikan siwa pribadi profesional yang mampu dan memanfaatkan teknologi untuk mengelola organisasi, sumberdaya, produksi dan kegiatan pemasaran.

4) Membangun jiwa entrepreneurship siswa agar mampu mengubah kondisi dari tantangan menjadi peluang sukses dunia-akhirat.

Keadaan dan jumlah dewan guru dan karyawan yang ada di SMP IT Bina Insani Kota Metro seluruhnya berjumlah 27 orang, Sementara siswa SMP IT Bina Insani Kota Metro berjumlah 150 an siswa. ${ }^{24}$

\footnotetext{
${ }^{24}$ Dokumen SMP IT Bina Insani Tahun Pelajaran 2017/2018
}

\section{HASIL PENELITIAN}

SMP IT Bina Insani Kota Metro merupakan sekolah Islam terpadu yang mengkombinasikan kurikulum nasional dengan materi-materi berbasis keagamaan (Islam) SMP IT Bina Insani Metro menerapkan kurikulum tingkat satuan pendidikan (KTSP) dan sedang mempersiapkan diri untuk menerapkan kurikulum 2013.

$$
\text { Pendidikan dilaksanakan }
$$

selama 3 tahun di mulai dari kelas VII sampai kelas IX. Struktur kurikulum disusun berdasarkan standar kompetensi lulusan yang memuat 10 mata pelajaran, muatan lokal dan pengembangan diri berupa tahsin, tahfidz, bahasa Arab dan komputer serta pembelajaran berbasis brain based learning dan multiple intelegencedan menjadikan program tahsin dan tahfidzsebagai program unggulan sekolah, siswa ditargetkan minimal hafal/hafidz2 juz (juz 29 dan 30) diakhir masa sekolah.Desain atau konsep pembelajaran sebagaimana tampak pada gambar dibawah ini.Konsep pembelajaran tahsin dan tahfidz

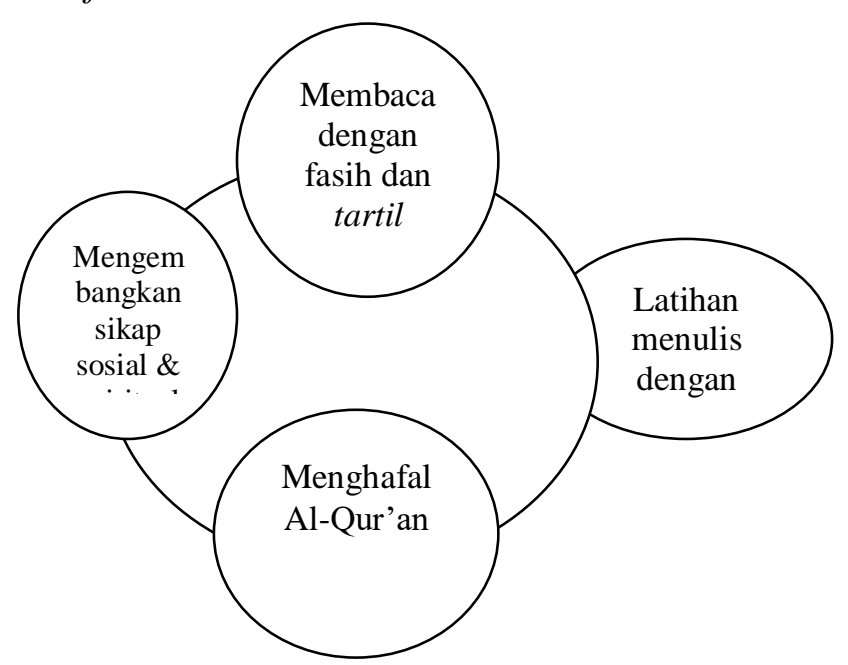


Pelaksanaan pelajaran tahsin dan tahfidz di SMP IT Bina Insani fokus pada pencapaian atau hasil hafalan Al-Qur'an para siswa selama menempuh masa pendidikan (tiga tahun) yang di terapkan melalui mata pelajaran yang diberikan secara terjadwal dan intensif 3 kali dalam satu minggu. Kegiatan belajar tahsin dan tahfidz di implementasikan melalui kegiatan talaqi, yaitu siswa di dalam kelas dibagi menjadi 3 halaqoh yang beranggotakan beberapa orang siswa sesuai dengan klasifikasi kemampuan masing-masing siswa yaitu kelompok tahsin iqro, kelompok tahsin Al-Qur'an dan kelompok tahfidz Al-Qur'an. Setiap kelompok didampingi oleh seorang guru atau ustadz yang memiliki kapasitas dan kapabilitas dalam bidang tahsin dan tahfidz, kegiatan menghafal dan setoran hafalan dilaksanakan dan pada saat berlangsungnya pelajaran atau dikenal dengan sistem ziadah.

Sebelum proses menghafal, siswa terlebih dahulu harus menguasai pelajaran tahsin,pelajaran tahsin dirancang untuk melatih dan memperbaiki bacaan (tilawah) AlQur'an siswa supaya menjadi baik dan benar melalui pengenalan dan penilaian penguasaan

hukum-hukum tajwid.Sebagai acuan, standar kompetensi siswa sebelum menghafal harus menguasai materi-materi sebagaimana tampak pada tabel di bawah ini.
Kompetensi membaca (tahsin) AlQur'an tingkat SMP

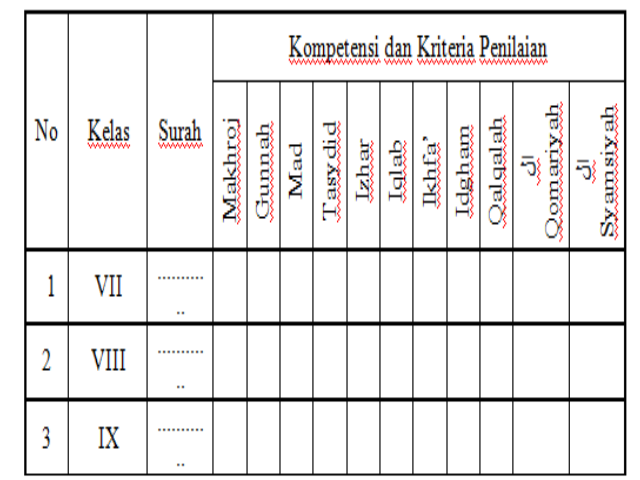

a. Tujuan pembelajaran tahsin dan tahfidz

Untuk mewujudkan tujuan pendidikan tahsin dan tahfidz, guru telah membuat konsep, strategi dan metode pembelajaran berupa silabus dan kontrak belajar. Berdasarkan hasil interview dengan guru 3 orang guru tahsin dan tahfiz diperoleh informasi bahwa tujuan mata pelajaran tahsin dan tahfidz adalah :

1) Sebagai konsekuensi dari program unggulan yang telah ditetapkan sekolah bahwa lulusan SMP IT Bina Insani Kota Metro harus memiliki kemampuan membaca dan menghafal Al-Qur'an yang baik.

2) Tahsin membentuk kompetensi bacaan (tilawah) Al-Qur'an dalam halpengenalan hukum tajwid dan mahrojul huruf sehingga siswa mahir dalam membaca dan menulis Al-Qur'an.

3) Tahfidz merupakan proses menghafal Al-Qur'an melalui pembiasaanmenghafalserta mempertahankan hafalannya, 
dengan demikian siswa akan menjadi generasi yang qur'ani.

4) Membantu mewujudkan kompetensi siswa dalam hal pemahaman pendidikan Islam. Melalui upaya gemarisasi membaca dan menghafal AlQur'an akan membantu mewujudkan kompetensi siswa dalam hal pemahaman pendidikan Islam dan menbambah kecerdasan siswa.

5) Agar siswa memiliki sikap spiritual dan terampil dalam beribadah sehari-hari. Hal ini menjadi sangat penting karena dimasa yang akan datang anakanak muslim terutama laki-laki harus dapat menjadi imam sholat baik bagi jamaah di masjid maupun bagi keluarganya.

b. Pola Pembelajaran dan Pelaksanaan Pelajaran Tahsin Dan Tahfidz Untuk mencapai tujuan pembelajaran, guru telah membuat sebuah pola belajar yang harus ditaati oleh siswa. Pelajaran tahsin dan tahfidz bukanlah sebuah pelajaran yang dapat mengakomodir metode-metode pembelajaran yang umum digunakan oleh guru akan tetapi keberhasilan pelajaran tahsin dan tahfidz dipengaruhi oleh frekuensi perjumpaan dengan rangsangan dan tugas yang dibuat. Dalam pelajaran ini, siswa makin menjadi baik penguasaannya jika kepada mereka diberikan lebih banyak kesempatan untuk mengulang atau berlatih muroja'ah karena mengulang pada hakikatnya adalah sebuah proses kembali mengingat-ingat atau rememori yang ada di dalam otak.

Pelajaran tahsin dan tahfidz diberikan 3 kali dalam satu minggu dengan waktu belajar yang telah ditetapkan, seperti pada kelas VIII Ikhwan (hari senin khusus tahsin hari selasa khusus tahfidz hari kamis khusus tahfidz). Dalam pelaksanaannya rombongan belajar dibuat terpisah antara ikhwan (laki-laki) dan akhwat (wanita) kecuali pada kelas IX ada satu kelas campuran yang berisi siswa ikhwan dan akhwat yang memiliki prestasi diatas rata-rata siswa pada umumnya.

Setiap pelajaran tahsin dan tahfidz berlangsung, kelas dibagi menjadi 3 kelompok kecil yang terdiri dari beberapa orang siswa dan 1 orang guru. Kelompok 1 membaca iqro', menghafal dan setor hafalan surat-surat pendek. Kelompok 2 membaca, menghafal dan setor hafalan juz 30 . Kelompok 3 membaca, menghafal dan setor hafalan juz 30 dan 29.

Sebelum proses menghafal, guru meneliti secara seksama cara membaca siswa, hal ini penting karena jika bacaan mulai dari harakat, panjang pendek hingga makhrajul huruf yang salah terlanjur dihafal oleh anak maka akan sulit untuk memperbaikinya. Berikut ini petikan catatan lapangan yang menggambarkan suasana proses kegiatan belajar mengajar pada pelajaran tahsin dan tahfidz:

1) Guru memberikan arahan bahwa pelajaran akan segera dimulai, dan meminta Siswa duduk dengan rapi dan tenang. 
2) Siswa aktif latihan mengeja huruf Arab, terutama surat yang pendek (juz 30)

3) Siswa mengidentifikasi perubahan bunyi huruf hijaiyah antar satu huruf yang satu dengan yang lain.

4) Siswa membiasakan diri untuk secara berulang-ulang membaca surat-surat pendek sampai hafal dan lancar

5) Pengesahan atau tashih, dilakukan menurut absensi maupun kesiapan dan kesediaan siswa. Siswa diwajibkan menghafal dan mendemonstrasikan atau menyetorkan hafalannya kepada guru pembimbing, wali kelas atau guru tahfidz dengan target 5 ayat disetiap pertemuan.

6) Setoran hafalan dilakukan minimal 3 kali dalam satu pekan dan dapat dilakukan sebelum atau sesudah pertemuan tatap muka.

7) Siswa yang hendak menyetorkan hafalannya, batas minimal hafalannya adalah sesuai urutan hafalannya dan tidak boleh lompat ke ayat atau surat selanjutnya.

8) Hafalan awal diulang bila ingin menyetor hafalan lanjutannya.

9) Bagi guru pembimbing, wali kelas atau guru yang ditunjuk berhak memberikan penilaian dengan lembar muroja'ah dan evaluasi belajar seperti dalam tabel dibawah ini.

Kompetensi hafalan (tahfidz) AlQur'an tingkat SMP

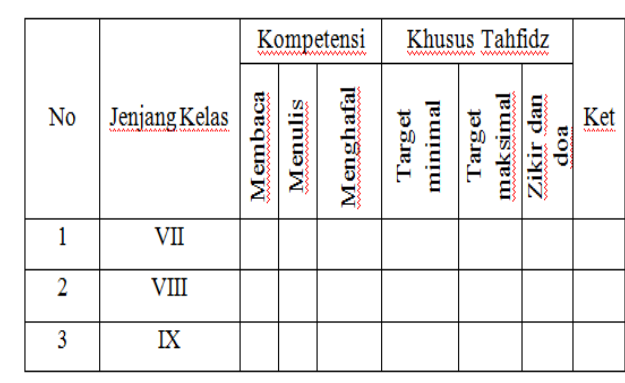

10) Bagi siswa yang belum dapat menyelesaikan hafalannya, maka ia terus berlatih dan berusaha memilih waktu-waktu yang baik untuk menghafal.

11) Percepatan atau akselerasi sangat dimungkinkan apabila siswa dapat lebih cepat menuntaskan hafalannya diluar target dan waktu yang telah ditentukan.

12) Muroja'ah atau pengulangan

Muroja'ah atau mengulang-ulang hafalan yang telah disetorkan bertujuan untuk merawat hafalan supaya tetap terpatri didalam memori otak. Kegiatan muroja'ah dapat dilakukan dimana saja, baik dalam waktu-waktu sholat maupun dalam aktivitas kehidupan seharihari seperti saat perjalanan pulang sekolah, bermain, beristirahat, duduk, berbaring atau keadaan yang lain.

E. PENERAPAN TARGHIB DAN TARHIB PADA PEMBELAJARAN TAHSIN DAN TAHFIDZ DI SMP IT BINA INSANI METRO

1. Penerapan Targhib

Berdasarkan dokumen tata tertib SMP IT Bina Insani Kota Metro pada BAB $X$ tentang Penghargaan, pelanggaran, sanksi, 
hukuman dan kafarat Pasal 34 point pertama menyatakan bahwa definisi penghargaan adalah "sesuatu yang diberikan kepada murid yang berprestasi dalam bidang akademik dan non akademik". Maksud dari pemberian reward adalah supaya dengan hadiah itu anak lebih giat lagi usahanya untuk memperbaiki dan meraih prestasi yang telah dapat dicapainya, dengan mendapatkan hadiah atau janji akan mendapatkan hadiah, anak menjadi lebih keras kemauannya untuk belajar dan berbuat lebih baik

Prestasi adalah sesuatu yang sangat berharga yang merupakan pengakuan terhadap penyelesaian sebuah tugas, usaha, partisipasi suatu pemerolehan keterampilan dan ilmu pengetahuan serta ungkapan terima kasih untuk antusiasnya, kesemuanya itu harus dan perlu mendapatkan apresiasi, tidak harus dengan wujud kegiatan perayaan yang meriah, hadiah dapat juga dalam bentuk ungkapan perasaan, acungan jempol disertai senyuman adalah sebuah penghargaan yang sangat bermakan bagi siswa.

Khusus pada pelajaran tahsin dan tahfidz, targhib di berikan bagi siswa yang memiliki prestasi, contohnya adalah :

1) Diakhir masa studi (kelulusan) setiap hafalan yang berhasil dikuasai siswa akan diberikan targhib atau reward berupa pemberian intensive finance atau dana bantuan belajar yang di sesuaikan dengan jumlah juz yang berhasil dihafal. Dana ini berasal dari yayasan yang ajukan dalam RAPBS. Menurut kepala sekolah SMP IT Bina Insani reward yang diberikan disesuaikan dengan jumlah juz yang berhasil di hafal oleh siswa. Berikut ini adalah klasifikasi reward yang diberikan oleh sekolah kepada siswa yang memiliki prestasi.

(a) Untuk hafalan lebih dari 2 juz, siswa diberikan targhib sebesar Rp 100.000,-

(b)Untuk hafalan lebih dari 3 juz, siswa diberikan targhib sebesar Rp 200.000,-

(c)Untuk hafalan lebih dari 4 juz, siswa diberikan targhib sebesar Rp 500.000,-

2) Setelah keseluruhan hafalan tuntas, maka siswa berhak di wisuda dan diberikan targhib berupa pemberian sertifikat/piagam tahfidz yang sangat berguna bagi siswa untuk melanjutkan ke tingkat pendidikan selanjutnya.

3) Dalam kegiatan belajar sehari-hari, siswa yang dapat menghafal melebihi target setiap pertemuan yaitu 5 ayat dalam setiap surat dalam Al-Qur'an. Targhib atau reward yang diberikan adalah guru memberikan atau membelikan anak makanan dan minuman ringan yang disukai seperti es teh, susu kedela.

4) Guru memberikan senyuman dan kalimat-kalimat sanjungan kepada anak yang berprestasi sebagai apresiasi dan penghargaan, sehingga anak akan merasa mendapat perhatian atas jerih payah belajar mereka. 


\section{Penerapan Tarhib}

Pada umumnya siswa dan siswi di SMP IT Bina Insani Kota Metro memiliki kepribadian yang baik, namun adakalanya perilaku lalai dan malas mendera beberapa siswa untuk melakukan aktivitas belajar karena tabiat manusia yang memang merupakan kombinasi antara kebaikan dan keburukan sehingga perlu mendapat pengarahan dan pengendalian

Tarhib di SMP IT Bina Insani Kota Metro biasa disebut dengan iqob, bersifat kasuistik dan hanya diberikan dalam keadaan-keadaan tertentu yaitu pada saat ada siswa atau siswi yang melakukan pelanggaran dan membutuhkan tindakan penanganan. Berdasarkan dokumen tata tertib SMP IT Bina Insani Kota Metro BAB X tentang penghargaan, pelanggaran, sanksi, hukuman dan kafarat Pasal 34 menyatakan bahwa "pelanggaran adalah tingkah laku siswa yang tidak sesuai dengan tata tertib sekolah sehingga perlu menerima sanksi". Penerapan tarhib untuk pelajaran tahsin dan tahfidz di SMP IT Bina Insani diserahkan sepenuhnya kepada guru, tarhib merupakan suatu tindakan guru kepada siswa yang melanggar peraturan dengan sengaja dan sadar dengan tujuan agar hukuman tersebut dapat membuat siswa menjadi sadar akan perbuatannya yang salah dan tidak lagi mengulangi perbuatannya tersebut.

1) Pelanggaran dan sanksi hukuman Sanksi adalah konsekuensi dari setiap pelanggaran dalam bentuk Surat Peringatan (SP) dan Droup Out (DO) yang dikeluarkan oleh pembina kedisiplinan kepada siswa yang melanggar peraturan dengan sengaja dan sadar, berdasarkan catatan lapangan yang penulis dapatkan, berikut ini adalah jenis-jenis pelanggaran beserta tarhib/iqob/sanksi di SMP IT Bina Insani Kota Metro:

a) Pelanggaran ringan yaitu pelanggaran yang dilakukan secara perorangan atau berkelompok, tetapi tidak mengganggu orang lain, dan tidak menganggu kelancaran kegiatan yang sedang berlangsung. Contoh :

(1) Lupa memberi salam atau menjawab salam

(2) Datang terlambat sampai 3 kali dalam sebulan

(3) Lalai dalam mengerjakan tugas yang diberikan oleh guru

(4) Tidak masuk sekolah tanpa keterangan sampai 3 kali

Sanksi yang diberikan adalah dengan diberikan teguran lisan

b) Pelanggaran sedang yaitu pelanggaran yang dilakukan secara perorangan atau berkelompok yang mengganggu orang lain, dan tidak menganggu kegiatan yang sedang berlangsung. Contoh:

(1) Tidak masuk sekolah tanpa keterangan lebih dari 3 kali

(2) Sengaja tidak mengenakan pakaian seragam yang telah ditentukan sekolah

(3) Berbicara dengan kasar atau membentak atau tidak senonoh.

(4) Tidak melakukan sholat wajib dengan berjamaah dan sholat dhuha. 
Sanksi yang diberikan adalah dengan diberikan teguran tertulis dengan warna kuning

c) Pelanggaran berat yaitu pelanggaran yang dilakukan secara perorangan atau berkelompok dengan melakukan perbuatan-perbuatan yang merugikan diri sendiri, orangorang di sekitar dan lingkungannya, serta syariat pokok, contoh :

(1) Sering berbicara bohong dan melawan pada guru maupun orang tua.

(2) Berkelahi, baik di sekolah maupun diluar sekolah.

(3) Mengkonsumsi narkoba dan atau gambar/video yang tidak senonoh.

(4) Menyepelekan aturan-aturan yang berlaku aturan agama, aturan pemerintah maupun tata tertib sekolah

Sanksi yang diberikan adalah dengan diberikan teguran tertulis dengan warna merah/dikeluarkan.

Substansi sanksi yang diberikan kepada siswa adalah kembali menyadarkan kesalahan yang telah diperbuat sehingga aktivitas yang dilakukan anak tidak lagi atas dasar paksaan atau tekanan, melainkan berdasarkan pada wa'yu atau kesadaran anak itu sendiri. Hukuman yang diberikan tidak merusak hubungan baik antara guru dan siswa, konsep hukuman telah dimengerti dan dipahami oleh anak, dengan demikian dampak dari hukuman itu anak tidak merasa didzalimi dan dengan pemberian hukuman tersebut anak diharapkan menjadi sadar akan perbuatannya yang salah dan tidak lagi mengulangi perbuatan tersebut.

Tarhib diberikan atas dasar rancangan belajar dan kontrak belajar yang telah disepakati antara siswa dengan guru SMPIT Bina Insani Kota Metro dipertemuan pertama kegiatan belajar mengajar, sebagaimana yang tertulis dalam Bab VIII Pasal 31 mengenai tahfidz dan halaqah.

1. Murid wajib mengikuti kelas tahfidz sesuai dengan jadwal dan tempat yang telah ditentukan dengan tertib.

2. Memperhatikan adab majelis dan adab terhadap Al-Qur'an.

3. Setiap murid berkewajiban memenuhi target hafalan yang telah ditentukan.

4. Mempersiapkan diri (fikriyyah, ruhiyyah dan jasadiyah) sebelum mengikuti kelas tahfidz.

5. Meminta izin kepada guru yang mengajar saat ingin meninggalkan kelas tahfidz karena suatu hal yang sangat penting dan mendesak.

6. Murid yang terlambat mengikuti kelas tahfidz harus meminta izin kepada guru yang mengajar.

7. Murid yang tidak masuk kelas tahfidz diharuskan mendapat surat keterangan dari wali kelas.

Berdasarkan uraian di atas, bahwasanya tarhib atau punishment yang diberikan terhadap siswa di SMP IT Bina Insani Kota Metro, telah sesuai dengan koridor pendidikan dan telah disepakati bersama, selain itu guru tidak pernah memberikan hukuman dalam bentuk pukulan, hukuman fisik memang diberikan seperti yang tersebut dalam point pertama, akan tetapi masih dalam tahap wajar dan 
tidak sampai membuat anak merasa sakit.

\section{F. KESIMPULAN}

Targhib wa tarhib di SMP IT Bina Insani telah dilaksanakan dengan baik Pemberian targhibatau reward lebih diutamakan daripada pemberian tarhib. Konsep pemberian tarhib lebih menekankan kepada pemberian treatment dalam rangka mendapat hasil yang lebih baik melalui cara yang bijak tanpa unsur kekerasan, mengintimidasi dan merendahkan fitrah, harkat dan martabat manusia disertai dengan upaya reinforcement atau mengembalikan semangat, cita-cita dan tujuan belajar tahsin dan tahfdiz.

Reaksi siswa terhadap penerapan tarhib dan targhib sangat beragam sesuai dengan karakter dan kemampuan anak, solusi atau jalan keluar yang dilakukan sekolah adalah pemberian targhib dan tarhibyang disesuaikan dengan rambu-rambu pendidikan. Guru pelajaran tahsin dan tahfidz menggunakan pendekatan dan pembinaan yang intensif kepada siswa dengan tidak pernah memberikan tarhib/iqob di luar koridor pendidikan seperti pukulan, hinaan dan cacian, hal ini ditandai dengan siswa tidak lagi merasa disakiti atau didzolimi karena sadar tarhib yang diberikan merupakan konsekuensi dari pelanggaran tata tertib dan kontrak belajar yang telah samasama disepakati.

\section{DAFTAR PUSTAKA}

Abd. Rosyid, Pandai, Baca, Tulis \& Tahfidz Al-Qur'an untuk SMP Kelas IX, Jakarta: Erlangga, 2014.

Ahmad Ali Budaiwi, Imbalan dan Hukuman Pengaruhnya Bagi Pendidikan Anak, Jakarta: Gema Insani Press, 2002.

Ahmad Tafsir, Ilmu Pendidikan dalam Perspektif Islam, Bandung: Remaja Rosda Karya, 2004.

Bagus Prayoga, Guru SMP IT Bina Insani Kota Metro, wawancara.

Basrowi dan Suwandi, Memahami Penelitian Kualitatif, Jakarta: Rineka Cipta, 2008.

Departemen Agama RI, Al-Quran dan Terjemahnya, Jakarta: CV. Diponegoro, 2000.

Depdikbud, Kamus Besar Bahasa Indonesia, Jakarta: Balai Pustaka, 2002.

Erwin Yudi Prahara, Metode Targhib Wa Tarhib dalam Pendidikan Islam, Jurnal Cendekia Vol.13 No.1, Januari-Juni 2015.

Dokumen SMP IT Bina Insani Tahun Pelajaran 2017/2018.

https://www.alsofwah.or.id/cetak hadits .php?id=247 diunduh tanggal 27 September 2018.

https://id.wikipedia.org/wiki/Tahsin diunduh tanggal 24 Oktober 2018

Luthfiana. Problematika implementasi educative 
punishment untuk anak usia dini Dan upaya solusinya di Tk Zainul Hasan Genggong Pajarakan Probolinggo. Skripsi IAIN Sunan Ampel. Surabaya : Program Studi Strata Satu Tarbiyah. 2008.

Mahmud Yunus, Kamus ArabIndonesia, Jakarta: PT. Mahmud Yunus Wadzurriyyah, 1989.

M. Ihsan Dacholfany, Inisiasi Strategi Manajemen Lembaga Pendidikan Islam Dalam Meningkatkan Mutu Sumber Daya Manusia Islam di Indonesia Dalam menghadapi Era Globalisasi, Jurnal AtTajdid, Volume 1, No.1 Januari-Juni, 2017

Rahman Assegaf, Aliran Pemikiran Pendidikan Islam Hadharah Keilmuan Tokoh Klasik Sampai Modern, Jakarta: PT. Raja Grafindo, 2012.

Ramayulis, Metodologi Pendidikan Agama Islam, Jakarta: Kalam Mulia,2005.

Slameto, Belajar dan faktor-faktor yang mempengaruhinya, Jakarta: Rineka Cipta, 2010.

Suryosubroto, B. Proses Belajar Mengajar Di Sekolah, Jakarta: PT Rineka Cipta, 2009.

Tim Sosiologi, Panduan Belajar Sosiologi, Jakarta: Yudhistira, 1994. 